\title{
INVITED REVIEW \\ Giardia duodenalis: INTER-STRAIN VARIABILITY OF PROTEINS, ANTIGENS, PROTEASES, ISOENZYMES AND NUCLEIC ACIDS
}

\author{
Semiramis GUIMARÃES(1), Maria Inês Leme SOGAYAR(1) \& Marcello F. de FRANCO(2)
}

\begin{abstract}
SUMMARY
Giardia duodenalis isolates from asymptomatic or symptomatic patients and from animals present similarities and differences in the protein composition, antigenic profile, pattern of proteases and isoenzymes, as well as in nucleic acids analysis.

In the present overview, these differences and similarities are reviewed with emphasis in the host-parasite interplay and possible mechanisms of virulence of the protozoon.
\end{abstract}

KEYWORDS: Giardia duodenalis; Review; Antigens; Isoenzymes; Proteases; Nucleic acids.

\section{INTRODUCTION}

Giardia, a flagellate found in the small intestine of mammals, birds, reptiles and amphibians, was first observed in 1681 by LEEUWENHOEK in his own feces and later by LAMBL in $1859^{125}$. The genus Giardia was created by KUNSTLER (1882) when he observed a flagellate in the intestine of tadpoles of amphibian anurans $^{71}$.

Giardia goes through a simple life cycle during which the parasite occurs in two distintic morphological forms, i.e., a trophozoite and a cyst. The trophozoite is piriform, bilaterally symmetrical and measures approximately $10-12 \mu \mathrm{m}$ in length by 5-7 $\mu \mathrm{m}$ in width. It presents four pairs of flagella and a ventral structure found only in the genus Giardia, denoted ventral disk or adhesive disk, which permits parasite adhesion to the intestinal mucosa of the host. Below the adhesive disk there are two parallel formations denoted median bodies which are found only in the genus Giardia and whose morphology has been used for species determination. With respect to internal organization, the trophozoites present two identical nuclei and no mitochondria. The Golgi complex was recently demonstrated in encysted trophozoites ${ }^{43,105}$.

The cyst is oval, $8-12 \mu \mathrm{m}$ long and $7-10 \mu \mathrm{m}$ wide, and has a $0.3-\mu \mathrm{m}$ thick outer wall of a glycoprotein nature denoted cystic wall. Internally there are two or four nuclei, flagellar axonemes, ribosomes and fragments of the ventral disk.

During the life cycle, the trophozoites adhering to the mucosa of the small intestine multiply by binary division and go through an encystation process. The cysts are excreted together with the feces of the host and may remain viable for several months in the environment. The cyst is the infecting form, which, after being ingested by the host, undergoes excystation in the duodenum and releases two trophozoites which divide by binary division, causing a new infection. Transmission occurs by fecal-oral contamination, with the host becoming infected by ingesting contaminated water and food, or from person to person through contaminated hands or through homosexual relations.

Giardia and giardiasis have been extensively studied over the last 15 years but fundamental questions continue to be unanswered despite all efforts. The taxonomy of Giardia is still controversial and species determination has been performed considering the host of origin and some morphological characteristics. Apparently, the host of origin is not a valid criterion since DNA analysis shows that Giardia species from different hosts are identical, whereas isolates from the same host may be markedly different ${ }^{90}$. On the other hand, many investigators consider the morphology of the median bodies to be the only feature that can be used as a differential criteria ${ }^{12,85}$. Thus, the genus Giardia can be divided into three species: Giardia duodenalis which infects mammals, birds and reptiles; Giardia muris which infects rodents, birds and reptiles; Giardia agilis which infects amphibians ${ }^{38}$. In addition to these three species, two others detected in birds in electron microscopy studies have been proposed, i.e., Giardia psittaci ${ }^{32}$ and Giardia ardeae $e^{33}$, respectively detected in parrots and in blue herons. Giardia lamblia and Giardia intestinalis are used as

(1) Departamento de Parasitologia, Instituto de Biociências, Campus de Botucatu/UNESP, Botucatu, SP, Brasil

(2) Departamento de Patologia, Escola Paulista de Medicina/UNIFESP, São Paulo, SP, Brasil.

Correspondence to: Marcello Franco, MD, Depto. Patologia, Escola Paulista de Medicina/UNIFESP, Rua Botucatu 740, 04023-900 São Paulo, SP, Brasil. Fax: 00.55.11.5719295. E-mail: mfranco@patologia.epm.br 
synonyms of $G$. duodenalis, especially for Giardia isolates of human origin. According to the norms of zoologic nomenclature, the species $G$. duodenalis is correct and the use of G. lamblia and G. intestinalis only contributes to increasing the confusion in the scientific literature ${ }^{127}$. Therefore, in this review, we will use $G$. duodenalis for all human isolates.

The development of axenic culture of Giardia, i.e., the establishment and growth of the parasite in culture media free from other organisms, has facilitated the study of the biology of the parasite ${ }^{3.84}$. Improved results with the axenic culture of the parasite were obtained after the development of a culture medium supplemented with bovine bile and cysteine ${ }^{66}$ and of techniques for in vitro excystation permitting the isolation, large-scale production and maintenance of the protozoa in the laboratory ${ }^{13,14,65,78,108}$. Most axenic isolates belong to the $G$. duodenalis group and are of human origin $^{129}$. A report of axenic culture of G. muris $^{45}$ is questionable since this species appears to be refractory to axenization ${ }^{127}$.

Giardiasis presents a cosmopolitan distribution, with 10 to $15 \%$ of the world population, on average, being infected. High prevalences ranging from 20 to $60 \%$ are commonly observed among children ${ }^{29,44,82,87}$, especially those living in institutions ${ }^{15,26,48,67,103}$.

The parasite can cause diarrhea associated with problems of malabsorption especially among children, leading to delayed growth and development. However, most infections are asymptomatic. This clinical variability has been attributed to factors related to the parasite (mechanical, proteolytic, immunologic), to the host (diet, intestinal motility, nutritional and immunologic status) and to host-parasite interactions (immune response and association with the intestinal microflora). The specific pathogenic mechanisms of Giardia, the factors responsible for the conversion of an asymptomatic infection to a symptomatic one and their impact on the host-parasite relationship still need investigation. In this review we shall present the most important studies on the characterization of $G$. duodenalis strains in which isoenzyme and protein patterns, protease activity and the antigenic and DNA characteristics of different isolates were investigated using biochemical, immunochemical and molecular techniques. These studies were conducted in order to expand the knowledge of this parasite and to detect differences between strains that might be associated with aspects of the host-parasite relationship and with the heterogeneity of clinical manifestations, immune response and effective treatment of human giardiasis.

\section{ELECTROPHORETIC ANALYSIS OF PROTEINS}

Most studies of giardiasis have used sodium duodecyl sulphate polyacrylamide gel electrophoresis (SDS-PAGE) for the analysis of the pattern of proteins present in various types of Giardia strain preparations. The knowledge of the composition and complexity of these strains might demonstrate characteristics that explain the variability in behavior in terms of virulence, infectivity, antigenicity, and drug resistance. In addition, analysis of the protein pattern represents a preliminary step in the characterization of proteins recognized by the immune system of the host.
The electrophoretic patterns of trophozoites kept in axenic cultures have been mainly obtained by fractionation of the total, cytoskeleton and plasma membrane proteins.

\section{Total proteins}

The first study for the characterization of axenic strains of $G$. duodenalis concerned the electrophoretic pattern of total proteins of trophozoites from four isolates obtained from symptomatic human patients originating from different geographic areas: WB (Afghanistan), Portland 1 (United States), RS (Ecuador), and LT (Puerto Rico). The results showed a high complexity in the composition of total proteins and a marked similarity of the electrophoretic patterns for the strains under study ${ }^{117}$.

Other studies later confirmed the similarity between $G$. duodenalis strains from the same location and even between strains obtained from hosts of different species ${ }^{17,136}$.

In contrast, ISAAC-RENTON et al. detected differences in the protein band patterns, demonstrating heterogeneity between human and animal strains, as well as between strains from hosts belonging to the same geographic area ${ }^{59}$.

In general, the electrophoretic patterns reported are complex, with the detection of multiple protein bands with molecular weights ranging from 10 to $140 \mathrm{kDa}^{117}$ or from 11 to $122 \mathrm{kDa}^{17}$.

\section{Cytoskeleton proteins}

The proteins associated with the cytoskeleton, together with plasma membrane proteins, play an important role in the antigenicity of human Giardia .

The cytoskeleton of Giardia consists of four systems of organelles composed of microtubules namely i) the ventral disk (adhesive disk), ii) the basal bodies, axonemes and flagella, iii) the median bodies and iv) the fibrils associated with the axonemes. The cytoskeleton of the adhesive disk is composed of adjacent microtubules adhering to the ventral surface of the plasma membrane through short filamentous processes ${ }^{56,119.120}$. Structures named microribbons partially surround each microtubule and project dorsally into the cytoplasm, being connected by fine filaments. These microribbons confer a striated aspect on the adhesive disk.

\subsection{Proteins of the adhesive disk}

A higher protein concentration is found in the ventral disk, with tubulin and giardin being the major components of the cytoskeleton $^{56}$.

Advances have been made in the biochemical characterization of proteins associated with the adhesive disk, especially after the development of procedures employing detergents for disk isolation ${ }^{57}$ and for dissociation of the subunits of the cytoskeletal proteins $^{24}$. 
GUIMARÃES, S.; SOGAYAR, M.I.L. \& FRANCO, M.F. de - Giardia duodenalis: inter-strain variability of proteins, antigens, proteases, isoenzymes and nucleic acids.

Rev. Inst. Med. trop. S. Paulo, 41 (1): 45-58, 1999.

Tubulin is the most abundant protein in the cytoskeleton of Giardia, representing the major component of microtubules. It is a dimer consisting of two subunits, $\alpha$ and $B$, which can be expressed in multiple forms. Five different forms of tubulin have been demonstrated in the cytoskeleton of Giardia ${ }^{49}$.

HOLBERTON \& WARD submitted adhesive disks obtained by extraction with Triton X-100 to SDS-PAGE and detected two close bands of 51 and $56 \mathrm{kDa}$ corresponding to the protein tubulin ${ }^{57}$. A smaller protein of $30 \mathrm{kDa}$ was later demonstrated and called giardin ${ }^{24}$.

Giardin corresponds to a group of specific proteins detected only in the adhesive disk of Giardia, with a molecular weight ranging from 29 to $38 \mathrm{kDa}^{7,24,58,102}$. The protein is found in the microribbons linked to the microtubules and corresponds to $20 \%$ of the proteins of the cytoskeleton. More than 13 different giardins have been identified thus far by two-dimensional electrophoresis, and the genes of two classes, $\alpha(33.8 \mathrm{kDa})$ and $\beta(29 \mathrm{kDa})$, have been cloned and sequenced ${ }^{102}$.

The biochemical characterization of the cytoskeletal proteins of Giardia has demonstrated that these proteins, present in different protozoan species, represent important targets for chemotherapeutic agents $^{28,100,102,115}$. With respect to Giardia, evidence has suggested that the mechanism of action of benzimidazoles, drugs recently used for the treatment of giardiasis, involves interaction with tubulins and/or giardins of the cytoskeleton ${ }^{106,107}$. Even though the function of the adhesive disk of Giardia has not been fully clarified, the microtubules and giardin, together with actin and myosin in this structure, are essential for the integrity of the parasite. Despite the presence of tubulin in the flagella of Giardia, flagellar activity is little affected by benzimidazoles since these compounds have greater affinity for tubulin and for the giardin of the adhesive disk, whose injury can cause the detachment of the parasite from the adhesion substrate ${ }^{127}$. Thus, agents that act directly on the cytoskeletal proteins of Giardia, especially on the adhesive disk, favor the development of efficient drugs for the treatment of the infection.

\section{Plasma membrane proteins}

Proteins associated with the plasma membrane, or surface proteins, of parasites are important both for the induction of the protective immune response and for the activation of effective immune mechanisms capable of destroying the parasites or of inhibiting their multiplication.

More detailed studies on the biochemical composition of the plasma membrane of Giardia have only recently been conducted. Most studies have used the external labeling of trophozoites with radioactive isotopes which permit the identification of the proteins exposed on the surface after SDS-PAGE fractionation and gel autoradiography.

Early studies using the external labeling of trophozoites of the WB and Portland 1 strains with radioactive iodine have revealed an intense electrophoretic band dispersed within the 94-225 kDa range ${ }^{88}$.
The electrophoretic patterns of the surface proteins of 19 isolates were later studied and identical patterns were detected only for the human strains WB, Isr (Israel), RS and LT, which presented a proeminent band corresponding to the $170 \mathrm{kDa}$ protein ${ }^{89}$.

More complex surface protein patterns were demonstrated in trophozoites of the WB, P-1, LT and RS strains labeled with ${ }^{225} \mathrm{I}$, which presented eight bands with molecular weights of 180, 105, $82,63,55,37,30$ and $24 \mathrm{kDa}^{22,31}$. Among the various proteins identified thus far on the membrane of radioisotope-labeled trophozoites, the protein of $82 \mathrm{kDa}$ has proved to be the most dominant ${ }^{30,31}$.

Significant advances in the study of surface proteins became possible after the standardization of techniques for the separation of the plasma membrane from the cytoplasm either by osmotic shock or by the formation of outer membranous vesicles induced at low detergent concentrations ${ }^{22}$.

SDS-PAGE analysis of the composition of plasma membrane fractions obtained from $G$. duodenalis trophozoites by this new methodology revealed an intense $75 \mathrm{kDa}$ band, a double band of 58$54 \mathrm{kDa}$, five bands between 38 and $30 \mathrm{kDa}$, a $22 \mathrm{kDa}$ band, and a region of diffuse bands in the $20-15 \mathrm{kDa}$ range ${ }^{22}$. Of these proteins, only those corresponding to the bands of 75, 58-54 and $22 \mathrm{kDa}$ were detected after autoradiography of ${ }^{125} \mathrm{I}$-labeled material. The major protein identified in the isolated membranes was that of $75 \mathrm{kDa}$, which probably corresponds to the protein of $82 \mathrm{kDa}$ detected in previous studies ${ }^{30,31}$. The proteins of $58-54 \mathrm{kDa}$ had a molecular weight similar to that of tubulin and probably correspond to a form of this protein on the membrane ${ }^{113,122}$.

\section{ANTIGENIC ANALYSIS}

Most human infections induced by Giardia are asymptomatic but in some situations they may be associated with symptoms including acute or persistent diarrhea, abdominal pain, malabsorption and flatulence. In general, the asymptomatic cases are spontaneously cured within a few weeks. Persons sporadically exposed to the parasite have a greater chance of developing the disease ${ }^{86}$, while persons frequently exposed to it are usually resistant ${ }^{15,44,60,103}$.

Even though protective immunity has not been conclusively demonstrated for human giardiasis, the development of an immune response has been suggested by evidence such as: i) the self-limiting nature of the infection; ii) the detection of specific anti-Giardia antibodies in the serum of affected individuals; iii) the participation of cytotoxic monocytes in the modulation of the immune response; iv) the greater susceptibility of immunocompromised individuals to the infection, especially among those with hypogammaglobulinemia; v) the lower susceptibility of individuals from areas where the infection is endemic compared to visitors; vi) chronic infection in athymic animal models or animals treated with drugs that depress the humoral response ${ }^{27}$.

Anti-Giardia antibodies have been identified in the serum of individuals from different regions in the world ${ }^{87,116,118}$. Studies on the specific immune response of human volunteers experimentally 
GUIMARÃES, S.; SOGAYAR, M.I.L. \& FRANCO, M.F. de - Giardia duodenalis: inter-strain variability of proteins, antigens, proteases, isoenzymes and nucleic acids. Rev. Inst. Med. trop. S. Paulo, 41 (1): 45-58, 1999.

infected with Giardia demonstrated the presence of $\operatorname{IgM}, \operatorname{IgG}$ and $\operatorname{IgA}$ in 100,70 and $60 \%$ of the patients, respectively ${ }^{92}$. Among asymptomatic adults, $14 \%$ presented serum anti-Giardia antibodies ${ }^{118}$. IgG antibodies were demonstrated in more than $80 \%$ of the patients with symptomatic giardiasis ${ }^{109}$ and the highest antibody titers were obtained in endemic areas, probably due to repeated exposure to the parasite ${ }^{116}$.

In addition to the role of serum antibodies, the participation of secretory $\operatorname{IgA}$ in local immunity has also been evaluated. In experimental murine infection, anti-Giardia $\operatorname{IgA}$ was detected in intestinal secretions, and a positive correlation between increased levels of this antibody and the rate of parasite elimination in the intestinal fluid was also observed ${ }^{52}$. Anti-Giardia IgA antibodies have been suggested to reduce the ability of trophozoites to adhere to the surface of intestinal epithelial cells ${ }^{64}$.

The increased frequency of giardiasis in individuals with altered humoral immunity, especially with IgA and IgG insufficiency, suggests that these immunoglobulins participate in the elimination of Giardia ${ }^{35}$.

The participation of cell immune mechanisms in giardiasis has also been recently considered, although the response has been more extensively studied in murine than in human giardiasis. The following observations made in experiments using animal models suggest the participation of T-dependent mechanisms: i) among experimentally infected athymic mice, only the animals capable of developing a lymphoproliferative response progress to a cure ${ }^{46}$; ii) an increased helper-suppressor $\mathrm{T}$ cell ratio was observed in the lamina propria of the jejunum of mice during the phase of convalescence from the infection ${ }^{133}$; iii) in man, there was an in vitro lymphoproliferative response of mononuclear cells and production of IL-2 by T CD4+ lymphocytes stimulated with $G$. duodenalis antigen ${ }^{47}$.

The development of an immune response for the control of Giardia infection may be associated with the recognition of certain antigenic components of the parasite ${ }^{30}$. A better understanding of the antigenic structure of this parasite may not only facilitate the analysis of the mechanisms of the immune response in the infection, but also open new perspectives for the immunologic diagnosis of giardiasis and reveal antigenic differences between parasite strains. These studies may determine whether the antigenic composition of a strain is related to its pathogenicity since evidence obtained from studies on animal models suggest that antigenically distinct organisms can induce different forms of the disease ${ }^{127}$.

Marked advances have been made in these studies only after the development of axenic Giardia culture which permitted obtaining adequate amounts of pure parasites with no contamination with other organisms such as bacteria and fungi. Furthermore, the development and standardization of sensitive immunochemical techniques have stimulated the investigation of Giardia proteins which are recognized by the antibodies of the host, and of the extent of antigenic heterogeneity among different parasite strains in different parts of the world.

Considerable diversity in the antigenic composition of axenic
Giardia strains has been detected in some studies ${ }^{88,89,116}$, while others have suggested that different strains can be antigenically similar ${ }^{17,136}$. The antigenic similarity between human and animal strains represents strong evidence of the possibility of transmission of giardiasis between different host species ${ }^{136}$.

Many antigens have been identified among trophozoite proteins since this is the parasite form found in the small intestine of the host, against which the immune response will be produced (Table 1). Important antigens have been detected in Giardia trophozoites mainly by immunoblotting, radioactive labeling with ${ }^{125} \mathrm{I}$ and immunoprecipitation techniques ${ }^{17,30,31,39,61,70,124,128,136,137}$.

Most Giardia antigens have been identified in reactions using polyclonal or monospecific antisera ${ }^{17,30,31,70,88,89,136}$. Specific monoclonal antibodies against surface proteins ${ }^{31,91}$ and also against cytoskeletal proteins ${ }^{128}$ have been produced in order to improve and facilitate the identification and characterization of the target antigens present in the trophozoites.

The dominant antigen detected in infected patients is a surface protein with a molecular weight of $30-34 \mathrm{kDa}^{61,124}$. Sera from patients with giardiasis acquired in North America, Asia, Africa or Europe strongly react with this protein, which, therefore, can represent an important epidemiological marker ${ }^{124}$. Other antigens commonly recognized in human infection are proteins of 82,56 , 28 and $27 \mathrm{kDa}^{30,124}$ (Table 1).

Since plasma membrane proteins interact first with the immune system of the host, great importance has been attributed to the identification of the major surface antigens present in trophozoites. Early studies have demonstrated the existence of antigen components on the surface which are eliminated in large amounts into the culture medium as excretion-secretion products. These antigens correspond to proteins of $94-225 \mathrm{kDa}^{88}$. Later study involving 19 axenic strains, including the standard strains WB and Portland 1, demonstrated marked antigenic differences related to this surface protein ${ }^{89}$.

Other surface antigens have been identified such as the proteins of $82 \mathrm{kDa}^{31}$ and $88 \mathrm{kDa}^{30}$, which seem to correspond to the same protein. Specific monoclonal antibodies for the $82 \mathrm{kDa}$ protein react with the membrane of the trophozoites, confirming the membrane localization of the antigen ${ }^{31}$. This component has been previously identified in different strains, and represents an important immunogen in Giardia infections. An $80 \mathrm{kDa}$ protein similar to the protein described in $G$. lamblia infection was identified as the major surface antigen recognized by antibodies of mice infected with $G$. muris ${ }^{54}$.

Other antigenic components present in Giardia trophozoites have been detected, with a predominance of the $62,52,38$ and $31 \mathrm{kDa}$ proteins ${ }^{17,39,136}$. The surface protein of $31-32 \mathrm{kDa}$ has been identified as an antigenic determinant in different human and animal isolates, and also is the major antigen recognized in natural human infection ${ }^{17,124}$. This $32 \mathrm{kDa}$ protein is present on the plasma membrane and adhesive disk and its amino acid sequence is identical to that of $\alpha$-1-giardin, which is one of the proteins present on the ventral disk ${ }^{137}$. Another important surface antigen component is the $170 \mathrm{kDa}$ protein, $12 \%$ of whose content corresponds to cysteine ${ }^{2}$. 
GUIMARÃES, S.; SOGAYAR, M.I.L. \& FRANCO, M.F. de - Giardia duodenalis: inter-strain variability of proteins, antigens, proteases, isoenzymes and nucleic acids. Rev. Inst. Med. trop. S. Paulo, 41 (1): 45-58, 1999.

TABLE 1

Giardia duodenalis antigens (modified from DEN HOLLANDER et al., 1988) ${ }^{27}$.

\begin{tabular}{lccc}
\hline $\begin{array}{c}\text { Molecular weight } \\
(\mathrm{kDa})\end{array}$ & Localization & $\begin{array}{c}\text { Antigenicity } \\
\text { established in/by }\end{array}$ & Proprieties \\
\hline 30 & Surface & Rabbits/Immunoppt & $\mathrm{NR}$ \\
31 & Surface & Humans/Immunoblt & $\mathrm{NR}$ \\
52 & Surface & Rabbits/Immunoblt & Glycoprotein \\
82 & Surface & Rabbits/Immunoblt & NR \\
& & Mice/Immunoppt & NR \\
88 & Surface & Humans/Immunoppt & Cytotoxic \\
88 & Surface & Mice/IF & Glycoprotein \\
170 & Surface/E-S & Rabbits/Immunoppt & Flagella \\
$94-225$ & Surface/E-S & Rabbits/Immunoppt & Tubulin \\
32 & Internal & Mice/Immunoblt-IF & Glycoprotein \\
$53-55$ & Internal & Mice/Immunoblt & NR \\
65 & Internal & Mice/Immunoblt-IF & In vivo/in vitro \\
170 & Internal & Rabbits/Immunoblt & In vivo/in vitro \\
21 & Cyst & Rabbits/Immunoblt & In vitro \\
28 & Cyst & Rabbits/Immunoblt & In vivo \\
36 & Cyst & Rabbits/Immunoblt & In vivo \\
49 & Cyst & Rabbits/Immunoblt & \\
65 & Cyst & &
\end{tabular}

IF - Immunofluorescence; Immunoblt- Immunobloting; Immunoppt- Immunoprecipitation; NR- Not reported; E-S (excretory-secretory)

Subcellular fractionation of trophozoites and the consequent production of cytoskeletal fractions became possible the recognition of tubulin-like molecules and the low molecular weight $(29-38 \mathrm{kDa})$ proteins present on the adhesive disk and called giardins ${ }^{25}$. Specific monoclonal antibodies for cytoskeletal proteins present in the trophozoite body and flagella recognized two antigens, of 170 and $155 \mathrm{kDa}$, in four strains from distinct geographic regions (USA, Afghanistan, Puerto Rico and Ecuador). The absence of reactivity of these antibodies in immunofluorescence with live trophozoites suggests that these antigenic determinants are not localized on the parasite's surface. In addition to these antigens, other polypeptides of 55 and $53 \mathrm{kDa}$ were recognized by monoclonal antibodies specific for the flagellum and adhesive disk. These components seem tubulin since they present a migration pattern similar to that of bovine brain tubulin and their respective monoclonal antibodies can react with this protein by immunoblotting ${ }^{128}$.

Relevant antigens present in trophozoites have been studied not only in terms of their localization but also with respect to their nature and properties (Table 1). Many Giardia antigens are glycoproteins that may be found on the surface as part of the cytoskeleton or in the internal structures of the microorganism. In addition to functioning as antigens, glycoproteins are important receptors in the interactions of protozoa with host cells, and also important components involved in the life cycle of the parasites.

With the use of lectins such as wheat germ agglutinin (WGA), it has been possible to determine the glycoprotein nature of different antigenic components of Giardia $^{55,99,134}$.

A $49 \mathrm{kDa}$ glycoprotein (gp 49) was demonstrated by Western blot on the surface of trophozoites of strains from different geographic areas ${ }^{83}$. There is evidence that the 28-30 kDa surface glycoprotein participates in the mechanism of trophozoite adhesion to the mucosa of the small intestine, in association with the adhesive disk $^{34}$. A $65 \mathrm{kDa}$ protein of $G$. duodenalis trophozoites has been classified as a glycoprotein since it can bind to the RCA I lectin (castor bean agglutinin), and this binding is inhibited by galactose $\mathrm{e}^{110}$. There is strong evidence that the $82 \mathrm{kDa}$ surface 
protein is also a glycoprotein since its electrophoretic mobility is altered by treatment with periodate, indicating the presence of carbohydrate residues ${ }^{31}$.

Some surface proteins have a high cysteine content and are known as cysteine-rich proteins. One of these antigens is the 170 $\mathrm{kDa}$ protein present on the plasma membrane of some strains and recognized by monoclonal antibodies that are specific and cytotoxic for trophozoites ${ }^{91}$. It is possible that this cytotoxic activity is responsible for the lysis of trophozoites present in the small intestine $e^{94}$.

Most studies have approached the antigenic characterization of trophozoites of Giardia strains. Studies conducted in order to characterize the cysts have expanded our knowledge of the antigenic composition of the parasite and have permitted the identification of specific antigens for the immunologic diagnosis of giardiasis. Specific antigens present in the cysts such as proteins with a molecular weight in the $66-103 \mathrm{kDa}$ range are recognized by antibodies produced in rabbits ${ }^{42,105}$. The $65 \mathrm{kDa}$ glycoprotein (GSA 65) has been considered to be an antigen shared by cysts and trophozoites of $G$. duodenalis. Furthermore, GSA 65 specifically occurs in Giardia and is the major antigen present in the feces of individuals with giardiasis. The antigen has been employed in the immunodiagnosis of giardiasis and has permitted the development of a commercial ELISA kit for the detection of GSA 65 in the feces of infected individuals ${ }^{111}$.

Despite these advances, there still is a need for comparative studies standardized in different laboratories in which standard strains may be analyzed together with test strains, in order to clarify the relationship of the differences existing among strains and of the immune response of the host with the pathogenicity of giardiasis.

\section{Antigenic variation}

There is evidence of the occurrence of the phenomenon of antigen variation in surface proteins in giardiasis. Several studies have demonstrated the occurrence of antigenic variation in Giardia in vitro $^{2,89,93}$ and in human ${ }^{95}$ and experimental ${ }^{4,5,47}$ infections.

The in vitro use of a cytotoxic monoclonal antibody against trophozoites from $G$. duodenalis isolates, which express the 170 $\mathrm{kDa}$ surface protein, demonstrated that a single trophozoite can give origin to organisms with different surface antigens ${ }^{1,93}$. When cloned trophozoites of the reference strain WB were exposed to this antibody, most of the organisms were destroyed. Analysis of the surface proteins of surviving trophozoites showed the appearance of a new antigen which was no longer recognized by the monoclonal antibody. Some of the clones analyzed presented the $64 \mathrm{kDa}$ protein replacing the $170 \mathrm{kDa}$ protein ${ }^{5,93}$.

Antigenic variation was demonstrated in vivo using mouse $\mathrm{e}^{47}$ and gerbil ${ }^{4}$ models. Gerbils were inoculated with the WB strain and the surface antigens of the trophozoites obtained from the intestine of the animals were studied during the course of infection ${ }^{4}$. The replacement of the original $170 \mathrm{kDa}$ antigen present on the surface of the cloned trophozoites with a new $92 \mathrm{kDa}$ antigen was demonstrated on the $7^{\text {th }}$ day of infection.

Antigenic variation was also demonstrated during the course of human infection when volunteers were inoculated with $G$. duodenalis trophozoites. The changes in the surface antigens were studied in cultures of trophozoites directly obtained from the small intestine. The $72 \mathrm{kDa}$ and $200 \mathrm{kDa}$ surface antigens were replaced with a new group of proteins between the $14^{\text {th }}$ and $22^{\text {nd }}$ day of infection $^{95}$.

In human infection, antibodies against variant antigens can be detected on the $14^{\text {th }}$ day of infection, with the humoral immune response possibly participating in the selection of these antigens. A different behavior is observed in gerbils, in which the changes of the antigens are visible between the $3^{\text {rd }}$ and $7^{\text {th }}$ day, preceding the period of antibody detection ${ }^{97}$.

The proteins involved in antigenic variation are called variantspecific surface proteins (VSPs) and, on the basis of their amino acid sequences, they correspond to a single protein family. They have different molecular weights ranging from 30 to $200 \mathrm{kDa}$ and are antigenically distinct ${ }^{97}$.

Electron microscopy techniques using labeling by specific monoclonal antibodies demonstrated that the variant proteins form a cover over the trophozoite surface, including the flagella ${ }^{92}$. They are not of a glycoprotein nature, but they have a high cysteine content $(11-12 \%)$

Organisms that express cysteine-rich proteins may present resistance to proteases. Thus, trypsin and chymotrypsin are cytotoxic to Giardia trophozoites of the WB strain, which express the $170 \mathrm{kDa}$ protein. However, the organisms that survive the action of these enzymes become resistant to these intestinal proteases and express surface antigens differing from those of the original strain. These observations suggest the possibility that resistance to proteases may be associated with the persistence of infection as a consequence of the selection of resistant surface proteins ${ }^{96}$.

The biological significance of the antigenic variation of Giardia is still speculative. This variation may possibly contribute to the chronicity of infection, suggesting parasite evasion of the host's immune response. Certain proteolysisresistant surface antigens permit the parasite to better survive in the intestine, a situation in which the process would be associated with a biochemical rather than with an immunological mechanism.

Furthermore, this process is believed to lead to increased diversity of the Giardia population, permitting the action of other selection processes $^{98}$.

\section{PROTEASE ANALYSIS}

Recent advances in the understanding of the biochemistry and molecular biology of protozoa have permitted the study of molecules 
GUIMARÃES, S.; SOGAYAR, M.I.L. \& FRANCO, M.F. de - Giardia duodenalis: inter-strain variability of proteins, antigens, proteases, isoenzymes and nucleic acids. Rev. Inst. Med. trop. S. Paulo, 41 (1): 45-58, 1999.

such as enzymes that directly participate in the parasite's life cycle or in the pathogenicity of the disease ${ }^{98}$.

Proteases are enzymes that catalyze the hydrolysis of peptide bonds in a protein and, by being specific for the substrate, offer clues to their in vivo function. The activity of proteases obtained from extracts of excretion-secretion products of protozoa may be measured using synthetic proteins or peptides as substrates. The substrate specificity shown by different proteases present in cell lysates can be demonstrated by the separation of these enzymes by electrophoresis and by the determination of their activity in situ. The methods of SDS-PAGE copolymerized with gelatin has permitted a comparison of the proteolytic activity of different enzymes on gelatin as a substrate. These studies have permitted detection of peptides that can be hydrolyzed by each enzyme $\mathrm{m}^{98}$.

Many protease inhibitors have been identified, and synthetic inhibitors represent important tools that permit the classification of these enzymes into four major groups: i) serine proteases, ii) cysteine proteases or thiol-proteases, iii) metalloproteases, and iv) aspartyl proteases $^{77}$.

In a review of several studies on the proteases of microorganisms, ${ }^{77}$ the functions for the proteases of parasites were reported as follows: i) to facilitate the invasion of host tissues, ii) to permit the parasites to digest specific host proteins that are important for its metabolism, iii) to help the parasite to escape the immune response of the host, iv) to participate in processes of parasite multiplication and differentiation and v) to degrade cytoskeletal proteins during the invasion or rupture of host cells ${ }^{77}$.

Many important parasite species such as Entamoeba histolytica, T. cruzi, Leishmania sp, Trichomonas vaginalis and Plasmodium sp are actively proteolytic and contain multiple proteases that directly participate in the life cycle, morphogenesis and infectivity of these protozoa $^{77}$.

With respect to Giardia, despite evidence that proteolysis is involved in its nutrition, development and pathogenicity, relatively little is known.

Early investigations demonstrated the cytochemical localization of acid phosphatase in vacuoles of $G$. duodenalis trophozoites functionally similar to lysosomes ${ }^{39,40}$. Starting from these observations, several hydrolases, including those with proteolytic activity, were demonstrated in extracts of axenically cultured trophozoites $^{74}$.

Initially, the intracellular activity of proteases in Giardia trophozoites was attributed to two major proteases corresponding to 105 and $40 \mathrm{kDa}$ bands detected by SDS-PAGE using gelatin as a substrate ${ }^{50,62}$.

More recent investigations, however, have demonstrated multiple proteases in $G$. duodenalis trophozoites, and not simply two enzymes $^{112,138}$. Eighteen proteases with molecular weights ranging from 30 to $211 \mathrm{kDa}$ have been detected thus far in trophozoite lysates ${ }^{138}$.
Most studies have investigated protease activities in trophozoites of the standard strains Portland 1 and WB, whereas few studies have been conducted on the protease activity of trophozoites of other axenic strains, especially comparing strains obtained from individuals with asymptomatic giardiasis to strains obtained from symptomatic individuals.

ALVARADO et al. ${ }^{8}$, using SDS-PAGE copolymerized with gelatin, studied protease activity in trophozoites of 10 axenic strains of $G$. duodenalis, six of which were isolated from asymptomatic carriers, two from patients with symptomatic giardiasis and the reference strains P-1 and WB. Proteolytic activity was demonstrated in all strains in which $10-15$ hydrolysis bands with molecular weight ranging from 185 to $16 \mathrm{kDa}$ were detected. The pattern of protease activity on the gel was similar in almost all strains despite the small difference associated with high molecular weight proteases detected in one strain isolated from a patient with symptomatic giardiasis.

Several studies have confirmed that the proteolytic activity of Giardia trophozoite lysates is predominantly due to cysteine proteases $^{50,74,100,112,138}$. For the characterization of these proteases, the effects of inhibitors, reducing substances and $\mathrm{pH}$ variation on proteolytic activity were mainly evaluated. With respect to the effects of inhibitors, inhibition of protease activity was observed when the trophozoite lysates were treated with specific cysteine proteinase inhibitors such as iodoacetamide, E-64 and leupeptin ${ }^{50,100,112,138}$. Treatment with TPCK ( $N$-tosyl-L-phenylalanine chloromethyl ketone) and TLCK (N $\alpha$-p-tosyl-L-lysine chloromethyl ketone) which act on cysteine proteases and serine proteases also inhibited the proteolytic activity of $G$. duodenalis ${ }^{50,138}$. Specific inhibitors of serine proteases such as phenylmethylsulfonyl fluoride (PMSF) and 4,4dichloroisocoumarin (DCI), and of aspartoproteases (pepstatin A) and metalloproteases (EDTA) did not modify the protease activity of Giardia ${ }^{50,138}$. Although most studies demonstrated that the proteolytic activity of Giardia trophozoites is mainly associated with cysteine proteases, some evidences have suggested the presence of some serine proteases and aspartoprotease ${ }^{138}$.

The marked presence of cysteine proteases in $G$. duodenalis is confirmed if we consider that the ideal $\mathrm{pH}$ for the activity of the proteases of this protozoa is in the 3.5-7 range and that this activity is increased by dithiothreitol (DDT), a reducing substance that protects cysteine proteases against oxidation, and consequently increases their activity ${ }^{50,100,112,138}$.

Speculations have been presented about the possible functions of these enzymes. One of them seems to be related to the life cycle of the parasite since the possible participation of cysteine proteases in the process of Giardia cyst differentiation to trophozoites (excystation) and from trophozoites to cysts (encystation) has been postulated.

Cysteine is an important amino acid in the biology of Giardia, as suggested by the following data: i) cysteine requirement for in vitro growth ${ }^{40}$, ii) expression of thiol groups on the surface of the trophozoite ${ }^{41}$, and iii) dominant surface antigens correspond to cysteine-rich proteins ${ }^{2}$. On this basis, cysteine proteases are 
GUIMARÃES, S.; SOGAYAR, M.I.L. \& FRANCO, M.F. de - Giardia duodenalis: inter-strain variability of proteins, antigens, proteases, isoenzymes and nucleic acids. Rev. Inst. Med. trop. S. Paulo, 41 (1): 45-58, 1999.

considered to participate in the metabolism and physiology of this parasite.

Although there still is no concrete evidence that trophozoites secrete proteases into the extracellular medium, the possibility has been proposed that, under certain conditions, these enzymes may be released into the extracellular medium, acting as a virulence factor and participating in the pathogenesis of giardiasis $^{100}$. Some data suggest that $G$. duodenalis can produce cytopathic effects on cell culture ${ }^{21}$. Among the proteases present in trophozoites, the $40 \mathrm{kDa}$ cysteine protease can cleave hemoglobin and immunoglobulin $\left(\operatorname{Ig} \mathrm{A}_{1}\right)$. This observation suggests that this protease permits the parasite to evade the immune response in the host's intestine by its ability to degrade immunoglobulins and to produce nonfunctional antibody fragments ${ }^{100}$.

Despite all of these observations, it has not yet been possible to confirm the real participation of proteases in the pathogenesis of giardiasis. Thus, the characterization of Giardia proteases still requires more detailed investigations mainly involving the purification of these enzymes since many investigators have proposed that these proteases may represent a potential target of chemotherapeutic agents ${ }^{77}$.

\section{ISOENZYME PATTERN}

Isoenzymes are distinct molecular forms of the same enzyme produced by different isolates of the same species. The various proteins that form a group of isoenzymes have similar, but not necessarily identical, enzymatic properties. For example, they can catalyze the same reaction but differ in terms of kinetics ${ }^{51}$.

Isoenzyme analysis has been an important biochemical tool employed in taxonomic studies of protozoa that parasitize man such as T. cruzi and Leishmania sp. This same technique has also been used for the characterization of pathogenic and non-pathogenic human strains of $E$. histolytica ${ }^{75}$. Furthermore, many studies of genetic variation in parasitic protozoa have employed isoenzyme electrophoresis, since the patterns obtained provide a large number of genetic markers.

The occurrence of isoenzymes has been demonstrated in different Giardia isolates and their importance for taxonomic studies and for the characterization of human and animal strains has been shown $n^{9,10,11,18,68,79,82,123 .}$

At least 26 isoenzyme systems have been used thus far for the characterization of Giardia isolates from the electrophoretic patterns of enzymes or zymodemes which seem to be a stable feature of the parasites. No differences in enzyme activity patterns were demonstrated when recently axenized isolates were compared with parasites maintained in vitro for three to six months ${ }^{18}$ or even with parasites cryopreserved twice over a period of one year ${ }^{10}$.

Several studies on Giardia have tried to demonstrate differences between the zymodemes of human and animal isolates ${ }^{11,79,81,123}$. The extent of variation among isolates differs according to geographic $\operatorname{area}^{11,79,104,123}$.

Considering this aspect, MELONI et al ${ }^{81}$ compared 39 Giardia isolates obtained from humans, cats, sheep and cattle from two different endemic areas, i.e., Australia and Switzerland. The results demonstrated a significant relationship between human and animal isolates in the two geographic areas. The establishment of a relationship between human isolates and isolates from other mammals in the same geographic area may be of important epidemiological significance, strongly indicating the possibility of cross-transmission between different hosts and consequently suggesting that giardiasis may be considered a zoonosis ${ }^{81}$.

In addition to detecting heterogeneity between different human strains of the parasite, analysis of isoenzyme patterns can also be used in an attempt to find a relationship between the degree of heterogeneity and the clinical course of infection. An association of Giardia zymodemes with the absence of symptoms has not yet been reported in humans since most studies only compared isolates obtained from symptomatic cases. However, CEDILLO-RIVERA et al. ${ }^{18}$, in a study of five strains from patients with symptomatic giardiasis and 14 strains from asymptomatic cases involving 10 isoenzyme systems, demonstrated great homogeneity between isolates and no marked difference between zymodemes that might be associated with the clinical form of infection.

\section{DNA ANALYSYS}

The application of DNA analysis methods has permitted the genetic characterization of different human parasites, including Giardia.

Heterogeneity among Giardia strains has been demonstrated by biochemical techniques, including analysis of isoenzyme patterns, protein electrophoresis and antigen analysis. Although no clear correlation has been shown between phenotypic variation and clinical presentation in giardiasis, genetic-molecular characterization can provide additional information for the study of pathogeny and epidemiology ${ }^{80}$. Large part of the phenotypic variability detected in Giardia is associated with genetic heterogeneity between strains, including those obtained from different hosts ${ }^{125}$.

Giardia is a binucleate protozoon and it is not yet clear whether these nuclei are morphologically and functionally identical. Some investigators have suggested that the nuclei are equivalent and that each one of them is haploid ${ }^{63}$. However, analyses of DNA content and of genome and karyotype conducted in different laboratories have presented conflicting results.

Studies on the characterization of Giardia DNA have been mainly based on karyotype analysis ${ }^{2,16,69,130,131}$ and on analysis of the fragments obtained with restriction enzymes ${ }^{80,90,131}$.

Karyotype analysis has been frequently employed by several investigators, with discrepant results. Electrophoresis of intact Giardia chromosomes in a pulsatile field detected at least five or six distinct groups (bands) of chromosomes ${ }^{2,16,131}$. The reported 
GUIMARÃES, S.; SOGAYAR, M.I.L. \& FRANCO, M.F. de - Giardia duodenalis: inter-strain variability of proteins, antigens, proteases, isoenzymes and nucleic acids. Rev. Inst. Med. trop. S. Paulo, 41 (1): 45-58, 1999.

size of these chromosomes ranged from approximately $1 \times 10^{6}$ to $4 \times 10^{6}$ base pairs (bp) ${ }^{2}$. More recently, the genome of Giardia was separated into at least nine chromosome groups ${ }^{69}$.

More recently, comparative studies between human and animal strains isolated from the same geographic region reported marked similarity between karyotypes ${ }^{2,16,130,131}$. In addition, DNA analysis of human strains isolated from symptomatic and asymptomatic cases demonstrated marked differences in number, size and intensity of chromosome bands, thus permitting a clear differentiation of the karyotypes of each $\operatorname{strain}^{69}$. These findings have been discussed in the light of the frequent occurrence of chromosome rearrangements during the culture and cloning of Giardia and of the possibility of mutation as a consequence of this phenomenon ${ }^{73}$.

Studies on the genetic variation of Giardia using the analysis of DNA fragments obtained after digestion with restriction endonucleases have demonstrated a marked diversity between parasite strains. The first analysis of DNA fragments from Giardia compared 12 strains isolated from human cases and three from animals and demonstrated that only four human strains and two animal strains presented identical DNA band patterns ${ }^{90}$. Later, the analysis of 47 strains ( 40 from humans and 7 from cats) distinguished 7 patterns of DNA bands ${ }^{80}$. There is no distinct pattern of DNA bands from strains isolated from humans or animals. The genetic differences between human strains isolated from different patients are often greater than the differences observed between species from different hosts. Thus, the absence of correlation between genetic variation and host can be evidence of cross transmission between man and animals ${ }^{80}$.

In order to expand the possibility of detecting genetic heterogeneity among Giardia strains, some studies have associated DNA analysis with isoenzyme analysis. Despite the differences in the amount of genetic variation detected with each of these methods, both of them assign the strains with identical band patterns to closely similar groups. The correlation between these techniques has suggested that these strain groups may represent natural clones of genetically identical organisms, or even a complex of similar species $^{80}$

The heterogeneity detected among Giardia strains on the basis of DNA analysis has confirmed evidence obtained in clinical, biological and biochemical studies which demonstrated a broad spectrum of genetic variation of the parasite. Furthermore, it should be emphasized that the occurrence of genetic variation in Giardia is of great value for i) the clarification of taxonomy, ii) the identification of markers associated with infectivity, virulence and drug resistance, and iii) a better understanding of the epidemiology, especially with respect to the patterns of transmission in different geographic areas.

\section{FINAL CONSIDERATIONS}

Giardiasis is currently considered to be an important public health problem in developing countries, where it is one of the most common causes of diarrhea among children. As a consequence of this infection, children often present problems of malnutrition and development ${ }^{127}$.

In these countries, the incidence of giardiasis is generally four times higher than in developed countries. Furthermore, the infection is inversely correlated with socioeconomic conditions, being high where hygiene standards are precarious ${ }^{127}$.

In Brazil, the prevalence of human infection with Giardia ranges from 4 to $30 \%$ and is endemic in many regions. In general, these rates have been determined from epidemiologic surveys mainly conducted on specific population groups such as children at daycare centers and schoolchildren.

In general, information about the host-parasite relationship accumulated over the years has been mainly obtained from investigations carried out in countries where giardiasis is not endemic.

In view of the importance of Giardia, approximately 25 years ago the Department of Parasitology of the Biosciences Institute, UNESP, Botucatu, initiated the study of this parasite. Several questions requiring additional in vitro studies arose after the early investigations. The Laboratory then invested into the implantation of axenic culture, which permitted the isolation of the first human strains in our country. Among these autochthonous strains are isolates obtained from individuals with asymptomatic giardiasis and from symptomatic patients

Considering that one of the questions most extensively investigated concerns the factors responsible for the development of symptomatic and asymptomatic infections, and the evidence that a given Giardia strain may have a higher potential for disease induction, it is important to conduct studies in an attempt to learn more about the strains isolated and axenized in Brazil in terms of their biochemical, antigenic, enzymatic, isoenzymatic, and molecular characteristics.

\section{RESUMO}

Giardia duodenalis: variabilidade da composição protéica e antigênica, de proteases e isoenzimas, e de ácidos nucléicos entre os isolados

Os isolados de Giardia duodenalis de indivíduos assintomáticos, de pacientes e de animais apresentam diferenças e semelhanças em sua composição protéica, expressão de antígenos, proteases e isoenzimas, assim como na constituição dos ácidos nucléicos.

A presente revisão analisa estas diferenças com ênfase na interação parasita e hospedeiro, e nos possíveis mecanismos de virulência do protozoário.

\section{ACKNOWLEDGMENTS}

We thank Mrs Elettra Greene for the English translation and Mrs Sheila de Freitas for the secretarial work. 


\section{REFERENCES}

1. ADAM, R.D.; AGGARWAL, A.; LAL, A.A. et al. - Antigenic variation of a cysteine-rich protein in Giardia lamblia. J. exp. Med., 167: 109-118, 1988

2. ADAM, R.D.; NASH, T.E. \& WELlEMS, T.E. - The Giardia lamblia trophozoite contain sets of closely related chromosomes. Nucleic Acids Res., 16: 4555-4567, 1988.

3. ADAM, R. D. - The biology of Giardia spp. Microbiol. Rev., 55: 706-732, 1991.

4. AGGARWAL, A. \& NASH, T.E. - Comparison of two antigenically distinct Giardia lamblia isolates in gerbils. Amer. J. trop. Med. Hyg., 36: 325-332, 1987.

5. AGGARWAL, A. \& NASH, T.E. - Antigenic variation of Giardia lamblia in vivo. Infect. Immun., 56: 1420-1423, 1988.

6. AGGARWAL, A.; MERRITT, J.W. \& NASH, T.E. - Cystein-rich variant surface proteins of Giardia lamblia. Molec. Biochem. Parasit., 32: $39-48,1989$

7. ALONSO, R.A. \& PEATTIE, D.A. - Nucleotide sequence of a second alpha giardin gene and molecular analysis of alpha giardin genes and transcripts in Giardia lamblia. Molec. Biochem. Parasit., 50: 95-104, 1992.

8. AlVARADO, L.; CEDIllo-RIVERA, R. \& MUNÕZ, O. - Analyses of protease activity in axenic isolates of Giardia lamblia. Arch. Med. Res., 23: 247,1991

9. ANDREWS, R.H.; ADAMS, M.; BOREHAM, P.F.L.; MAYRHOFER, G. \& MELONI, B.P. - Giardia intestinalis: electrophoretic evidence for a species complex. Int. J. Parasit., 19: 183-190, 1989.

10. BAVEJA, U.K.; JYOTI, A.S.; KAUR, M. et al. - Isoenzyme studies of Giardia lamblia isolated from symptomatic cases. Aust. J. exp. Biol. med. Sci., 64: $119-126,1986$

11. BERTRAM, M.A.; MEYER, E.A.; LILE, J.D. \& MORSE, S.A. - A comparison of five axenic Giardia isolates. J. Parasit., 69: 793-801, 1983.

12. BERTRAM, M.A.; MEYER, E.A.; ANDERSON, D.L. \& JONES, C.T. - A morphometric comparison of five axenic Giardia isolates. J. Parasit., 70: $530-535,1984$

13. BHATIA, V.M. \& WARHURST, D.C. - Hatching and subsequent cultivation of cysts of Giardia intestinalis in Diamond's medium. J. trop. Med. Hyg., 84: 45, 1981 .

14. BINGHAM, A. K. \& MEYER, E.A. - Giardia excystation can be induced in vitro in acidic solutions. Nature (Lond.), 277: 301-302, 1979.

15. BLACK, R.E.; DYKES, A.C.; SINCLAIR, S.P. \& WELLS, J.G. - Giardiasis in day-care centers. Evidence of person to person transmission. Pediatrics, 60: 486-491, 1977.

16. CAMPBELL, S.R.; VAN KEULEN, H.; ERLANDSEN, S.L.; SENTURIA, J.B. \& JARROLL, E.L. - Giardia sp.: a comparison of electrophoretic karyotypes. Exp. Parasit., 71: 470-482, 1990.
17. CAPON, A.G.; UPCROFT, J.A.; BOREHAM, P.F.L.; COTTIS, L. \& BUNDESEN, P.G. - Similarities of Giardia antigens derived from human and animal sources. Int. J. Parasit., 19: 91-98, 1989.

18. CEDILLO-RIVERA, R.; ENCISO-MORENO, J.A.; MARTINEZ-PALOMO, A. \& ORTEGA-PIERRES, G. - Giardia lamblia: isoenzyme analysis of 19 axenic strains isolated from symptomatic and asymptomatic patients in Mexico. Trans. roy. Soc. trop. Med. Hyg., 83: 644-646, 1989.

19. CHAR, S.; SHETTY, N.; NARASIMHA, M. et al. - Serum antibody response in children with Giardia lamblia infection and identification of an immunodominant 57-kilodalton antigen. Paras. Immunol., 13: 329-337, 1991

20. CHAUdhuri, P. ; DE, A.; BHATTACHARYA, A.; PAL, S.CH. \& DAS, P. Detection of specific anti-Giardia antibodies in the serodiagnosis of symptomatic giardiasis. J. Diarr. Dis. Res., 10: 151-155, 1991.

21. CHÁVEZ, B.; KNAIPPE, F.; GONZÁLEZ-MARISCAL, L. \& MARTÍNEZPALOMO, A. - Giardia lamblia: electrophysiology and ultrastructure of cytopathology in cultured epithelial cells. Exp. Parasitol., 61:379-389, 1986.

22. CLARK, J.T. \& HOLBERTON, D.V. - Plasma membrane isolated from Giardia lamblia: identification of membrane proteins. Europ. Cell. Biol., 42: 200-206, 1986

23. COOMBS, G.H. - Proteinases of Leishmania mexicana and other flagellate protozoa. Parasitology, 84: 149-155, 1982.

24. CROSSLEY, R. \& HOLBERTON, D.V. - Characterization of proteins from cytoskeleton of Giardia lamblia. J. Cell Sci., 59: 81-103, 1983.

25. CROSSLEY, R. ; MARSHALL, J. \& HOLBERTON, D.V. - Immunocytochemical differentiation of microtubules in the cytoskeleton of Giardia lamblia using monoclonal antibodies to alpha-tubulin and polyclonal antibodies to associated low molecular weight proteins. J. Cell Sci., 80: 233-235, 1986.

26. DANCINGER, M. \& LOPEZ, M. - Numbers of Giardia in the feces of infected children. Amer. J. trop. Med. Hyg., 24: 237-242, 1975.

27. DEN HOLLANDER, N.; RILEY, D. \& BEFUS, D. - Immunology of giardiasis. Parasit. today, 4: 124-131, 1988.

28. DE SOUZA, W. - Cell biology of Trypanosoma cruzi. Int. Rev. Cytol., 86: $197-283,1984$

29. DUPONT, H.L. \& SULLIVAN, P.S. - Giardiasis: the clinical spectrum, diagnosis and therapy. Pediat. infect. Dis., 5:131-138, 1986.

30. EDSON, C.M.; FARTHING, M.J.G.; THORLEY-LAWSON, D.A. \& KEUSCH, G.T. - Na 88,000-M Giardia lamblia surface protein which is immunogenic in humans. Infect. Immun., 54: 621-625, 1986.

31. EINFELD, D.A. \& STIBBS, H.H. - Identification and characterization of a major surface antigen of Giardia lamblia. Infect. Immun., 46: 377-383, 1984

32. ERLANDSEN, S.L.; BEMRICK, W.J. \& PAWLEY, J. - SEM evidence for a new species, Giardia psittaci. J. Parasit., 73: 623-629, 1987

33. ERLANDSEN, S.L.; BEMRICK, W.J.; WELLS, C.L. et al. - Axenic culture and characterization of Giardia ardeae from the great blue heron (Ardea herodias). J. Parasit., 76: 717-724, 1990. 
GUIMARÃES, S.; SOGAYAR, M.I.L. \& FRANCO, M.F. de - Giardia duodenalis: inter-strain variability of proteins, antigens, proteases, isoenzymes and nucleic acids. Rev. Inst. Med. trop. S. Paulo, 41 (1): 45-58, 1999.

34. FARTHING, M.J.G.; MATA, L.; URRUTIA, J.J. \& KRONMAL, R.A. - Natural history of Giardia infection of infants and children in rural Guatemala and its impact on physical growth. Amer. J . clin. Nutr., 43: 395-405, 1986.

35. FARTHING, M.J.G. - Host-parasite interactions in human giardiasis. Quart. J. Med., 70: 191-204, 1989.

36. FEELY, D.E. \& ERLANDSEN, S.L. - Morphology of Giardia agilis: observation by scanning electron microscopy and interference reflexion microscopy of acid phosphatase. J. Parasit., 77: 441-448, 1985.

37. FEELY, D.E. \& DYER, J.K. - Localization of acid phosphatase activity in Giardia lamblia and Giardia muris trophozoites. J. Protozool., 34: 80-83, 1987.

38. FILICE, F.P. - Studies on the cytology and life history of a Giardia from the laboratory rat. Univ. Calif. Publ. Zool., 57: 53-145, 1952.

39. FORREST, M.; ISSAC-RENTON, J. \& BOWIE, W. - Immunoblot patterns of Giardia duodenalis isolates from different hosts and geographical locations. Canad. J. Microbiol., 36:42-46, 1990.

40. GILLIN, F.D. \& DIAMOND, L. - Entamoeba histolytica and Giardia lamblia: effects of cysteine and oxygen tension on trophozoites attachment to glass and survival in culture media. Exp. Parasit., 52: 9-17, 1981.

41. GILLIN, F.D.; REINER, D.S.; LEVY, R.B. \& HENKART, P.A. - Thiol groups on the surface of anaerobic parasitic protozoa. Molec. Biochem. Parasit., 13: $1-12,1984$.

42. GILLIN, F.D.; REINER, D.S.; GAULT, M.J. et al. - Encystation and expression of cyst antigens by Giardia lamblia in vitro. Science, 235: 1040-1043, 1987.

43. GILLIN, F.D.; REINER, D.S. \& McCAFFREY, M. - Organelles of protein transport in Giardia lamblia. Parasit. today, 7: 113-116, 1991.

44. GILMAN, R.H.; BROWN, K.H.; VISVESVARA, G.S. et al. - Epidemiology and serology of Giardia lamblia in developing country: Bangladesh. Trans. roy. Soc. trop. Med. Hyg., 79: 469-473, 1985.

45. GONZALEZ-CASTRO, J.; BERMEJO-VICEDO, M.T. \& PALACIOSGONZALEZ, F. - Desenquistamiento y cultivo de Giardia muris. Rev. Iber. Parasit., 46: 21-25, 1986.

46. GOTTSTEIN, B. \& NASH, T.E. - Antigenic variation in Giardia lamblia: infection of congenitally athymic nude and scid mice. Paras. Immunol., 13: 649-659, 1991 .

47. GOTTSTEIN, B.; STOCKS, N.I.; SHEARER, G.M. \& NASH, T.E.- Human cellular immune response to Giardia lamblia. Infection, 19: 421-426, 1991.

48. GUIMARÃES, S. \& SOGAYAR, M.I.L. - Occurrence of Giardia lamblia in municipal day-care centers from Botucatu, São Paulo State, Brazil. Rev. Inst. Med. trop. S. Paulo, 37: 501-506, 1995.

49. HANCOCK, K. \& TSANG, V.C.W. - India ink staining of proteins on nitrocellulose paper. Analyt. Biochem., 133: 157-162, 1983.

50. HARE, D.F.; JARROL, E.L. \& LINDMARK, D.G. - Giardia lamblia: characterization of proteinase activity in trophozoites. Exp. Parasit., 68: $168-175,1989$.
51. HARRIS, H. \& HOPKINS, D.A. - Handbook of enzyme electrophoresis in human genetics. Amsterdam, North Holland Publishing, 1976.

52. HEYWORTH, M.F. - Antibody response to Giardia muris trophozoites in mouse intestine. Infect. Immun., 52: 568-571, 1986.

53. HEYWORTH, M.F. - Immunology of Giardia and Cryptosporidium infections. J. infect. Dis., 166: 465-472, 1992.

54. HEYWORTH, M.F. \& VERGARA, J.A. - Giardia muris trophozoites antigenic targets for mouse intestinal IgA antibody. J. infect. Dis., 169: 395-398, 1994.

55. HILL, D.R.; HEWLETT, E.L. \& PEARSON, R.D. - Lectin binding by Giardia lamblia. Infect. Immun., 34: 733-738, 1981.

56. HOLBERTON, D.V. - Fine structure of the ventral disc apparatus and the mechanism of attachment in the flagellate Giardia muris. J. Cell Sci., 13: 11-41, 1973 .

57. HOLBERTON, D.V. \& WARD, A.P. - Isolation of the cytoskeleton of Giardia. Tubulin and low molecular weight protein associated with microribbon structures. J. Cell Sci., 47: 139-166, 1981.

58. HOLBERTON, D.; BAKER, D.A. \& MARSHALL, J. - Segmented alphahelical coiled-coil structure of the protein giardin from the Giardia cytoskeleton. J. Molec. Biol., 204: 789-795, 1988.

59. ISAAC-RENTON, J.L.; BYRNE, S.K. \& PRAMEYA, R. - Isoelectric focusing of ten strains of Giardia duodenalis. J. Parasit., 74: 1054 -1056, 1988.

60. ISLAM, A.; STOLL, B. J.; LJUNGSTRÖM, I. et al. - Giardia lamblia infections in a cohort of Bangladesh mothers and infants followed for one year. J. Pediatrics, 103: 996-1000, 1983.

61. JANOFF, E.N.; SMITH, P.D. \& BLASER, M.J. - Acute antibody responses to Giardia lamblia are depressed in patients with AIDS. J. infect Dis., 157: 798-804, 1988.

62. JARROLL, E.L.; GASPANO, J.; HARE, D.F. \& LINDMARK, D.G. Proteinases of Giardia. In: LLOYD, D.; COOMBS, G.H. \& PAGET, T.A. Biochemistry and molecular Biology of anaerobic Protozoa. Switzerland, Harwood Academic Publishers, 1989. p. 202-216.

63. KABNICK, K.S. \& PEATTIE, D.A. - In situ analyses reveal that the two nuclei of Giardia lamblia are equivalent. J. Cell Sci., 95: 353-360, 1990.

64. KAPLAN, B.S.; UNI, S.; AIKAWA, M. \& MAHMOUD, A.A.F. - Effector mechanism of host resistance in murine giardiasis: specific IgG and IgA cell-mediated toxicity. J. Immunol., 134: 1975-1981, 1985.

65. KASPRZAK, W. \& MAJEWSKA, A.C. - Infectivity of Giardia sp. cysts in relation to eosin exclusion and excystation in vitro. Tropenmed. Parasit., 34: 70-72, 1983.

66. KEISTER, D.B. - Axenic culture of Giardia lamblia in TYI-S-33 medium supplemented with bile. Trans. roy. Soc. trop. Med. Hyg., 77: 487$488,1983$.

67. KEYSTONE, J.S.; KRAJDEN, S. \& WARREN, M.R. - Person to person transmission of Giardia lamblia in day-care nurseries. Canad. med. Ass. J., 119: 241-258, 1978 . 
GUIMARÃES, S.; SOGAYAR, M.I.L. \& FRANCO, M.F. de - Giardia duodenalis: inter-strain variability of proteins, antigens, proteases, isoenzymes and nucleic acids. Rev. Inst. Med. trop. S. Paulo, 41 (1): 45-58, 1999.

68. KORMAN, S.H.; LE BLANCQ, S.M.; SPIRA, D.T. et al. - Giardia lamblia identification of different strains from man. Z. Parasitenk., 72: 173180,1986

69. KORMAN, S.H.; LE BLANCQ, S.M.; DECKELBAUM, R.J. \& VAN DER PLOEG, L.H.T. - Investigation of human giardiasis by karyotype analysis. J. clin. Invest., 89: 1725-1733, 1992.

70. KUMKUM; KHANNA, R.; KHULLER, M.; MEHTA, S. \& VINAYAK, V.K. - Plasma membrane associated antigens of trophozoites of axenic Giardia lamblia. Trans. roy. Soc. trop. Med. Hyg., 82: 439-444, 1988.

71. KUNSTLER, J. - Sur cinq protozoaires parasites nouveaus. C. R. Soc. Biol. (Paris), 95: 347-349, 1882

72. LAEMMLI, U.K. - Cleavage of structural proteins during the assembly of the head of bacteriophage T4. Nature (Lond.), 277: 680-685, 1970.

73. LE BLANCQ, S.M.; KORMAN, S.H. \& VAN DER PLOEG, L.H.T. - Frequent rearrangements of rRNA-encoding chromosomes in Giardia lamblia. Nucleic Acids Res., 19: 4405-4412, 1991.

74. LINDMARK, D.G. - Giardia lamblia: localization of hydrolase activity in lysosome-like organelles in trophozoites. Exp. Parasit., 65: 141-147, 1988.

75. MARTINEZ-PALOMO, A. - The pathogenesis of amoebiasis. Parasit. today, 3: $166-175,1987$

76. MATA, L.J. - The children of Santa Maria Cauque: a prospective field study of the health and growth. Cambridge, Mass., MIT Press, 1978.

77. McKERROW, J.H.; SUN, E.; ROSENTHAL, J. \& BOUVIER, J. - The proteases and pathogenicity of parasitic protozoa. Ann. Rev. Microbiol., 47: 821-853, 1993

78. MELONI, B.P. \& THOMPSON, R.C.A. - Comparative studies on the axenic in vitro cultivation of Giardia of human and canine origin: evidence for intraspecific variation. Trans. roy. Soc. trop. Med. Hyg., 81: 637-640, 1987.

79. MELONI, B.P.; LYMBERY, A.J. \& THOMPSON, R.C.A. - Isoenzyme electrophoresis of 30 isolates of Giardia from humans and felines. Amer. J. trop. Med. Hyg., 38: 65-73, 1988.

80. MELONI, B.P.; LYMBERY, A.J. \& THOMPSON, R.C.A. - Characterization of Giardia isolates using a non-radiolabeled DNA probe, and correlation with the results of isoenzyme analysis. Amer. J. trop. Med. Hyg., 40: 629-637, 1989.

81. MELONI, B.P.; THOMPSON, R.C.A.; STRADEN, A.M.; KOHLER, P. \& ECKERT, J. - Critical comparison of Giardia duodenalis from Australia and Switzerland using isoenzyme electrophoresis. Acta trop. (Basel), 50: $115-124,1992$.

82. MELONI, B.P.; THOMPSON, R.C.A.; HOPKINS, R.M.; REYNOLDSON J.A. \& GRACEY, M. - The prevalence of Giardia and other intestinal parasites in children, dogs and cats from Aboriginal communities in the Kimberley. Med. J. Aust., 158: 157-159, 1993

83. MENG, T.C.; DAS, S.; REINER, D.S.; ALEY, S.B. \& GILLIN, F.D. - Variable and common surface antigens of Giardia lamblia. J. Cell. Biol., 111: 322a, 1990.
84. MEYER, E.A. - Giardia lamblia: isolation and axenic cultivation. Exp. Parasit., 39: 101-105, 1976

85. MEYER, E.A. \& RADULESCU, S. - Giardia and giardiasis. Advanc. Parasit., 17: 1-14, 1979

86. MEYER, E.A. - Preface. In: MEYER, E.A. Giardiasis. Amsterdam, Elsevier 1990. p. $1-9$

87. MIOTTI, P.G.; GILMAN, R.H.; SANTOSHAM, M.; RYDER, R.W. \& YOLKEN, T.H. - Age-related rate of serum positivity and antibody to Giardia lamblia in four diverse populations. J. clin. Microbiol., 24: 972-975, 1986.

88. NASH, T.E.; GILLIN, F.D. \& SMITH, P.D. - Excretory-secretory products of Giardia lamblia. J. Immunol., 131: 2004-2010, 1983

89. NASH, T.E. \& KEISTER, D.B. - Differences in excretory-secretory products and surface antigens among 19 isolates of Giardia. J. infect. Dis., 152: $1166-1171,1985$

90. NASH, T.E.; McCUTCHAN, D.; KEISTER, D. et al. - Restrictionendonuclease analysis of DNA from 15 Giardia isolates obtained from humans and animals. J. infect. Dis., 152: 64-73, 1985

91. NASH, T.E. \& AGGARWAL, A. - Cytotoxicity of monoclonal antibodies to a subset of Giardia isolates. J. Immunol., 136: 2628-2632, 1986.

92. NASH, T.E.; HERRINGTON, D.A.; LOSONSKY, G.A. \& LEVINE, M.M. Experimental human infection with Giardia lamblia. J. infect. Dis., 156: 974-984, 1987.

93. NASH, T.E.; AGGARWAL, A.; ADAM, R.D.; CONRAD, J.T. \& MERRITT J.W. - Antigenic variation in Giardia lamblia. J. Immunol., 141: 636641,1988

94. NASH, T.E. - Antigenic variation in Giardia lamblia. Exp. Parasit., 68: 238-241, 1989.

95. NASH, T.E.; BANKS, S.M.; ALLIN, D.W.; MERRITT, J.W. \& CONRAD J.T. - Frequency of variant antigens in Giardia lamblia. Exp. Parasit., 71: 415-442, 1990.

96. NASH, T.E.; MERRITT, J.W. \& CONRAD, J.T. - Isolate and epitope variability in susceptibility of Giardia lamblia to intestinal proteases. Infect. Immunol., 59: 1334-1340, 1991

97. NASH, T.E. - Surface antigen variability and variation in Giardia lamblia. Parasit. today, 8: 229-234, 1992

98. NORTH, M.J.; MOTTRAM, J.C. \& COOMBS, G.H. - Cysteine proteinases of parasitic protozoa. Parasit. today, 6: 270-275, 1990

99. ORTEGA-BARRIA, E.; WARD, H.D.; EVANS, J.E. \& PEREIRA, M.E.A - N-acetyl-D-glucosamine is present in cysts and trophozoites of Giardia lamblia and serves as a receptor for wheatgerm agglutinin Molec. Biochem. Parasit., 43: 151-166, 1990

100. PARENTI, D.M. - Characterization of a thiol proteinase in Giardia lamblia. J. infect. Dis., 160: 1076-1080, 1989

101.PEATTIE, D.M. - The giardins of Giardia lamblia: genes and proteins promise. Parasit. today, 6: 52-56, 1990. 
GUIMARÃES, S.; SOGAYAR, M.I.L. \& FRANCO, M.F. de - Giardia duodenalis: inter-strain variability of proteins, antigens, proteases, isoenzymes and nucleic acids Rev. Inst. Med. trop. S. Paulo, 41 (1): 45-58, 1999.

102. PEATtie, D.M. AlONSO, R.A.; HEIN, A. \& CAULFIELD, J.P. Ultrastructural localization of giardins to the edges of disc microribbons of Giardia lamblia and the nucleotide and deduced protein sequence of alpha giardin. J. Cell Biol., 109: 2323-2325, 1989

103.PICKERING, L.K.; WOODWARD, W.E.; DUPONT, H.L. \& SULLIVAN, P. - Occurrence of Giardia lamblia in children in day-care centers Pediatrics, 104: 522-526, 1984.

104. PROCTOR, E.M.; ISAAC-RENTON, J.L.; BOYD, J.; WONG, Q. \& BOWIE W.R. - Isoenzyme analysis of human and animal isolates of Giardia duodenalis from British Columbia, Canada. Amer. J. trop. Med. Hyg., 41: $411-415,1989$

105. REINER, D.S. MCCAFFERY, M \& GILLIN, F.D. - Sorting of cyst wall proteins to a regulated secretory pathway during differentiation of the primitive eukaryote, Giardia lamblia. Europ. J. Cell Biol., 53: 142153, 1990.

106. REYNOLDSON, J.A.; THOMPSON, R.C.A. \& MELONI, B.P. - In vivo efficacy of albendazole against Giardia duodenalis in mice. Parasit. Res., 77: 325-328, 1991.

107. REYNOLDSON, J.A.; THOMPSON, R.C.A. \& MELONI, B.P. - The potential and possible mode of action of the benzimidazoles against Giardia and other protozoa. J. pharm. Med., 2: 35-50, 1992.

108. RICE, E.W. \& SCHAEFER, F.W. - Improved in vitro excystation procedure for Giardia lamblia cysts. J. clin. Microbiol., 14: 709-710, 1981.

109. RIDLEY, M.J. \& RIDLEY, D.S. - Serum antibodies and jejunal histology in giardiasis associated with malabsorption. J. clin. Path., 29: 30-34 1976.

110. ROSOFF, J.D. \& STIBBS, H.H. - Isolation and identification of a Giardia lamblia-specific stool antigen (GSA 65) useful in coprodiagnosis of giardiasis. J. clin. Microbiol., 23: 905-910, 1986

111. ROSOFF, J.D.; SANDERS, C.A.; SONNAD, S.S. et al, - Stool diagnosis of giardiasis using a commercially available enzyme immunoassay to detect Giardia-specific antigen 65 (GSA 65). J. clin. Microbiol., 27: 1997 2002, 1989

112. ROBERTSON, C.D.; IRVINE, J.W.; BROWN, K. et al. - Proteinases of Giardia lamblia trophozoites. Trans. roy. Soc. trop. Med. Hyg., 85: 844,1991

113. RUBIN, R.W. - Membrane tubulin: factor or fiction? BioEssays, 1: 157$160,1984$.

114. RUSSELL, D.G. \& DUBREMETZ, J.F. - Microtubular cytoskeletons of parasitic protozoa. Parasit. today, 2: 177-179, 1986

115. SEEBECK, T.; HEMPHILL, A. \& LAWSON, D. - The cytoskeleton of trypanosomes. Parasit. today, 6: 49-52, 1990

116. SMITH, P.D.; GILLIN, F.D.; BROWN, W.R. \& NASH, T.E. - IgG antibody to Giardia lamblia detected by enzyme-linked immunosorbent assay. Gastroenterology, 80: 1476-1480, 1981.

117. SMITH, P.D.; GILLIN, F.D.; SPIRA, W.M. \& NASH, T.E. - Antigenic analysis of Giardia lamblia from Afghanistan, Puerto Rico, Ecuador, and Oregon. Infect. Immun., 36: 714-719, 1982
118. SMITH, P.D. - Pathophysiology and immunology of giardiasis. Ann. Rev. Med., 36: 295-307, 1985 .

119. SOGAYAR, M.I.L. \& GREGÓRIO, E.A. - Cytoplasmic inclusions in Giardia: an electron microscopy study. Ann. trop. Med. Parasit., 80: 49-52, 1986.

120. SOGAYAR, M.I.L. \& GREGÓRIO, E.A.-Ultrastructure of Giardia duodenalis trophozoites group from hamster: some relevant aspects. Mem. Inst. Oswaldo Cruz, 86: 443-446, 1991.

121.SOGAYAR, M.I.L.; RAMOS, M.A.M.; MENEGUIN, J.M. \& SOGAYAR, R. - Primeiras cepas de Giardia sp de origem humana, isoladas em meio axênico no Brasil. In: CONGRESSO BRASILEIRO DE PARASITOLOGIA, 11., 1989, Rio de Janeiro, 1989. p. 26.

122. STEPHENS, R.E.-Chemical differences distinguish ciliary membrane and axonemal tubulins. Biochemistry, 20: 4716-4723, 1981

123.STRANDÉN, A.M.; ECKERT, J. \& KÖHLER, P. - Electrophoretic characterization of 30 isolates of Giardia from humans, cattle, sheep and a dog in Switzerland. J. Parasit., 76: 660-668, 1990.

124.TAYLOR, G.D. \& WENMAN, W.M. - Human immune response to Giardia lamblia infection. J. infect. Dis., 155: 137-140, 1987.

125. THOMPSON, R.C.A.; LYMBERY, A.J. \& MELONI, B.P. - Genetic variation in Giardia Kunstler, 1982: taxonomic and epidemiological significance. Protozool. Abst., 14: 1-28, 1990

126. THOMPSON, R.C.A. - Parasitic zoonoses - problems created by people, no animals. Int. J. Parasit., 22: 555-561, 1992

127.THOMPSON, R.C.A.; REYNOLDSON, J.A. \& MENDIS, A.H. - Giardia and giardiasis. Advanc. Parasit., 32: 71-160, 1993.

128. TORIAN, B.E.; BARNES, R.C.; STEPHENS, R.S. \& STIBBS, H.H. - Tubulin and high-molecular-weight polypeptides as Giardia lamblia antigens. Infect. Immun., 46: 152-158, 1984

129. UDEZULU, I.A.; VISVESVARA, G.S.; MOSS, D.M. \& LEITCH, G.J. Isolation of two Giardia lamblia (WB strain) clones with distinct surface protein and antigenic profiles and differing infectivity and virulence. Infect. Immun., 60: 2274-2280, 1992

130. UJI, A.; WALLIS, P.M. \& WENMAN, W.M. - Comparison of Giardia isolates by DNA-DNA hybridization. In: WALLIS, P. \& HAMMOND, B.R. Advances in Giardia research. Alberta, University of Calgary Press, 1988. p. 165-167.

131. UPCROFT, J.A.; BOREHAM, P.F.L.\& UPCROFT, P. - Geographic variation in Giardia karyotypes. Int. J. Parasit., 19: 519-527, 1989.

132. UPCROFT, J.A.; MITCHELL, R. \& BOREHAM, P.F.L. - DNA fingerprinting of the intestinal parasite Giardia duodenalis with the M 13 phage genome. Int. J. Parasit., 20: 319-323, 1990.

133. VINAYAK, V.K.; KHANNA, R. \& KUM, K. - Kinetics of intraepithelium and lamina propria lymphocyte responses during Giardia lamblia infection in mice. Microb. Pathog., 10: 343-350, 1991

134. WARD, H.D.; ALROY, J.; LEV, B.I.; KEUSCH, G.T. \& PEREIRA, M.E.A. - Biology of Giardia lamblia - detection of N-acetyl-D-glucosamine as the only surface saccharide moiety and identification of two distinct subsets of trophozoites by lectin binding. J. exp. Med., 167: 73-88, 1988. 
GUIMARÃES, S.; SOGAYAR, M.I.L. \& FRANCO, M.F. de - Giardia duodenalis: inter-strain variability of proteins, antigens, proteases, isoenzymes and nucleic acids. Rev. Inst. Med. trop. S. Paulo, 41 (1): 45-58, 1999.

135. WARREN, K.S. - Selective primary health care and parasitic diseases. In: McAdam, K.P.W.J., ed. New strategies in Parasitology. Edinburgh, Churchill Livingstone, 1989. p.107-129.

136. WENMAN, W.M.; MEUSER, R.V. \& WALLIS, P.M. - Antigenic analysis of Giardia duodenalis strains isolated in Alberta. Canad. J. Microbiol., 32: 926-929, 1986
137. WENMAN, W.M.; MEUSER, R.U.; NYUGEN, Q. et al. - Characterization of an immunodominant Giardia lamblia protein antigen related to alpha giardin. Parasit. Res., 79: 587-592, 1993.

138. WILliAMS, A.G. \& COOMBS, G.H. - Multiple protease activities in Giardia intestinalis trophozoites. Int. J. Parasit., 25: 771-778, 1995.

Received: 02 October 1998

Accepted: 09 October 1998 